This item was submitted to Loughborough's Research Repository by the author.

Items in Figshare are protected by copyright, with all rights reserved, unless otherwise indicated.

\title{
N2 fixation and cycling in Alnus glutinosa, Betula pendula and Fagus sylvatica woodland exposed to free air $\mathrm{CO} 2$ enrichment
}

PLEASE CITE THE PUBLISHED VERSION

http://dx.doi.org/10.1007/s00442-011-2197-4

PUBLISHER

(c) Springer-Verlag

VERSION

AM (Accepted Manuscript)

LICENCE

CC BY-NC-ND 4.0

\section{REPOSITORY RECORD}

Millett, Jonathan, Douglas Godbold, Andrew R. Smith, and Helen Grant. 2011. "N2 Fixation and Cycling in Alnus Glutinosa, Betula Pendula and Fagus Sylvatica Woodland Exposed to Free Air CO2 Enrichment". Loughborough University. https://hdl.handle.net/2134/13433. 
This item was submitted to Loughborough's Institutional Repository (https://dspace.lboro.ac.uk/) by the author and is made available under the following Creative Commons Licence conditions.

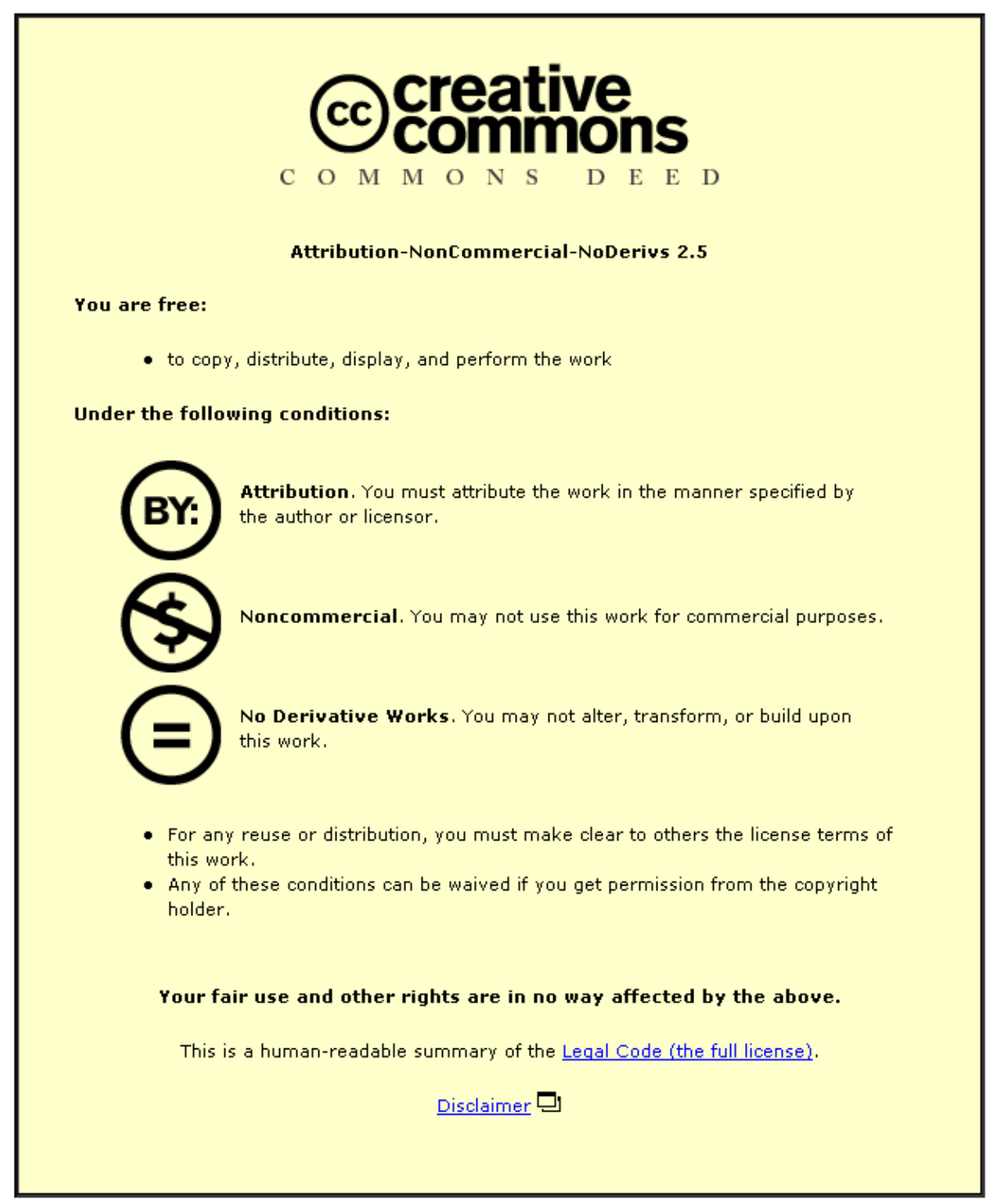

For the full text of this licence, please go to: http://creativecommons.org/licenses/by-nc-nd/2.5/ 
$1 \quad \mathbf{N}_{2}$ fixation and cycling in Alnus glutinosa,

2 Betula pendula and Fagus sylvatica woodland

3 exposed to free air $\mathrm{CO}_{2}$ enrichment.

4

5

6

7

Jonathan Millett ${ }^{1^{*}}$, Douglas Godbold ${ }^{2}$, Andrew R Smith ${ }^{2}$ and Helen Grant ${ }^{3}$

${ }^{1}$ Centre for Hydrological and Ecosystem Science, Department of Geography, Loughborough University, Loughborough, LE11 3TN, UK

2 School of Environment, Natural Resources and Geography, University of Wales, Bangor, Gwynedd, LL57 2UW, UK

${ }^{3}$ Centre for Ecology \& Hydrology, Lancaster Environment Centre, Library Avenue, Bailrigg, Lancaster., LA1 4AP, UK

*Corresponding author: j.millett@lboro.ac.uk, T: +44 (0)1509 222739, F: (0)1509 223930

Author contributions: JM conceived and designed the study, carried out sample collection, analysed data and wrote the manuscript. DG conceived, designed and set up BangorFACE. ARS carried out soil sampling and analysis. HG carried out stable isotope analysis. DG, ARS and HG provided comments on the manuscript. The authors declare that they have no conflicts of interest. 
We measured the effect of elevated atmospheric $\mathrm{CO}_{2}$ on atmospheric nitrogen $\left(\mathrm{N}_{2}\right)$ fixation for the tree species Alnus glutinosa growing in monoculture or in mixture with the non- $\mathrm{N}_{2-}$ fixing tree species Betula pendula and Fagus sylvatica. We addressed the hypotheses that 1: $\mathrm{N}_{2}$ fixation in A. glutinosa will increase in response to increased atmospheric $\mathrm{CO}_{2}$ concentrations, when growing in monoculture, 2: the impact of elevated $\mathrm{CO}_{2}$ on $\mathrm{N}_{2}$ fixation in A. glutinosa is the same in mixture and in monoculture and 3: the impacts of elevated $\mathrm{CO}_{2}$ on $\mathrm{N}$ cycling will be evident in a decrease in leaf $\delta^{15} \mathrm{~N}$ and in the soil-leaf enrichment factor (EF), and that these impacts will not differ between mixed and single species stands. Trees were grown in a forest plantation on former agricultural fields for 4 growing seasons, after which the trees were on average $3.8 \mathrm{~m}$ tall and canopy closure had occurred. Atmospheric $\mathrm{CO}_{2}$ concentrations were maintained at either ambient or elevated (by $200 \mathrm{ppm}$ ) concentrations using a free-air $\mathrm{CO}_{2}$ enrichment (FACE) system. Leaf $\delta^{15} \mathrm{~N}$ was measured and used to estimate the amount $\left(\mathrm{N}_{\mathrm{dfa}}\right)$ and proportion $\left(\% \mathrm{~N}_{\mathrm{dfa}}\right)$ of $\mathrm{N}$ derived from atmospheric fixation. On average $62 \%$ of the $\mathrm{N}$ in A. glutinosa leaves was from fixation. $\% \mathrm{~N}_{\mathrm{dfa}}$ and $\mathrm{N}_{\mathrm{dfa}}$ for A. glutinosa trees in monoculture did not increase under elevated $\mathrm{CO}_{2}$, despite higher growth rates. However, $\mathrm{N}_{2}$ fixation did increase for trees growing in mixture, despite the absence of significant growth stimulation. There was evidence that fixed $\mathrm{N}_{2}$ was transferred from A. glutinosa to F. sylvatica and B. pendula, but no evidence that this affected their $\mathrm{CO}_{2}$ response. This study shows that $\mathrm{N}_{2}$ fixation in A. glutinosa may be higher in a future elevated $\mathrm{CO}_{2}$ world, but that this effect will only occur where the trees are growing in mixed species stands.

53 Key words: FACE; ${ }^{15} \mathrm{~N}$ natural abundance; greenhouse gasses; forest ecology; plant 54 interactions. 
Human manipulation of the carbon $(\mathrm{C})$ cycle has increased the concentration of Carbon

Dioxide $\left(\mathrm{CO}_{2}\right)$ in the atmosphere, with future increases expected to have large environmental impacts (Soloman et al. 2007). Forest ecosystems play an important role in the global C cycle because they contain almost $60 \%$ of global terrestrial C (Grace 2004) and contribute approx. $50-60 \%$ of terrestrial net primary productivity (Saugier et al. 2001). As a result they exchange large amounts of $\mathrm{CO}_{2}$ with the atmosphere and are important sinks for anthropogenic $\mathrm{CO}_{2}$ emissions (Pacala et al. 2001; Saugier et al. 2001; Janssens et al. 2003).

Tree growth is limited by present atmospheric $\mathrm{CO}_{2}$ concentrations (Long et al. 2004) and so is predicted to be stimulated by elevated atmospheric $\mathrm{CO}_{2}$ (Norby et al. 2005). However, tree growth in natural systems is also regularly limited by nitrogen $(\mathrm{N})$ availability (Körner 2003; Millard et al. 2007). Furthermore, trees may become increasingly N-limited as atmospheric $\mathrm{CO}_{2}$ concentrations rise, because increased growth is accompanied by increased $\mathrm{N}$ requirement which may not be met by increased root $\mathrm{N}$ uptake (Luo et al. 2004). As a result the 'fertilisation' effect of elevated $\mathrm{CO}_{2}$ may be reduced (Oren et al. 2001; Ainsworth and Long 2005; Reich et al. 2006b). However, elevated $\mathrm{CO}_{2}$ might also stimulate increased $\mathrm{N}$ uptake (Finzi et al. 2007), through increased plant investment in $\mathrm{N}$ capture to support increased growth. This strong interdependence between $\mathrm{N}$ and $\mathrm{C}$ use means that understanding the interactions between elevated atmospheric $\mathrm{CO}_{2}$ and $\mathrm{N}$ use and cycling in forests is essential, for the accurate prediction of future global $\mathrm{C}$ dynamics (Reich et al. 2006a). In particular the role of atmospheric $\mathrm{N}_{2}$ fixation in plant and ecosystem responses to elevated $\mathrm{CO}_{2}$ has been relatively little studied in forest ecosystems.

By directly accessing $\mathrm{N}$ fixed from the atmosphere by symbiotic bacteria, $\mathrm{N}_{2}$-fixing plants are able to reduce their reliance on root-derived $\mathrm{N}$ to some extent (Postgate 1998; Vessey et al. 2005). Furthermore, $\mathrm{N}_{2}$ fixation is an important source of $\mathrm{N}$ for forest ecosystems, providing on average between $1.8-25.4 \mathrm{~kg} \mathrm{~N}^{-1}$ globally, and up to $150 \mathrm{~kg} \mathrm{~N} \mathrm{ha}^{-1}$ in temperate 
81 forests (Cleveland et al. 1999). $\mathrm{N}_{2}$ fixation in trees may be stimulated by elevated $\mathrm{CO}_{2}$

82 (Hungate et al. 1999; Temperton et al. 2003; Feng et al. 2004) due to increased carbon supply

83 to root nodules (Tissue et al. 1997). However, this effect may disappear in the long term due to changes in light availability and/or reduced supply of other nutrients (e.g phosphorous, iron and molybdenum) (Hungate et al. 2004). Therefore, the growth of $\mathrm{N}_{2}$-fixing plants may show a different response to elevated $\mathrm{CO}_{2}$ than non- $\mathrm{N}_{2}$-fixing plants, at least when $\mathrm{N}$ availability is limiting (Bucher et al. 1998; Poorter and Navas 2003). For example, in the only FACE (free-air $\mathrm{CO}_{2}$ enrichment) experiment to-date to have included an $\mathrm{N}_{2}$-fixing tree species, Eguchi et al. (2008) found that the photosynthetic response of alder saplings was different to that of birch saplings. Down regulation of photosynthesis occurred in birch under elevated $\mathrm{CO}_{2}$; for alder down regulation of photosynthesis occurred in fertile soil, but not in infertile soil.

Plants rarely grow in isolation and their response to elevated $\mathrm{CO}_{2}$ can be affected by the extent and type of plant-plant interactions they experience (Poorter and Navas 2003). Plant responses to elevated $\mathrm{CO}_{2}$ when growing with other plants are poorly predicted by performance in isolation (Poorter and Navas 2003). Additionally, the impact of elevated $\mathrm{CO}_{2}$ on plant performance in mixture can differ from the impact on plant performance in monoculture. Therefore, it is important to measure plant responses to elevated $\mathrm{CO}_{2}$ when growing in different combinations of species. For example, $\mathrm{N}$ limitation in the entire plant community can be reduced when $\mathrm{N}_{2}$-fixing plants are present (Roggy et al. 2004; Daudin and Sierra 2008), which might influence the response of the community to elevated $\mathrm{CO}_{2}$. FACE studies in grassland systems have shown that the $\mathrm{CO}_{2}$ effect on legume $\mathrm{N}_{2}$ fixation is similar in mixed and single species communities (Lee et al. 2003). The presence of $\mathrm{N}_{2}$-fixing plants in these communities enhanced leaf $\mathrm{N}$ content and photosynthesis in co-occurring non- $\mathrm{N}_{2}-$ fixing plants, but did not affect the $\mathrm{CO}_{2}$ response of these plants. No FACE studies in forest 
systems have included mixed species stands containing $\mathrm{N}_{2}$-fixing tree species. Therefore, it is not clear how $\mathrm{N}_{2}$-fixing and their non- $\mathrm{N}_{2}$-fixing neighbours and will respond in mixed species stands.

When growing with $\mathrm{N}_{2}$-fixing plants, non- $\mathrm{N}_{2}$-fixing plants may be able to access some fixed $\mathrm{N}$ through direct transfer by release from nodulated roots, along common mychorrhizal networks or indirectly through decomposition of nodules, roots or aboveground litter (He et al. 2003; Roggy et al. 2004; Daudin and Sierra 2008). This facilitative plant-plant interaction can provide a significant proportion of the total $\mathrm{N}$ requirements of non- $\mathrm{N}_{2}$-fixing plants. For example, significant amounts of the $\mathrm{N}$ in non- $\mathrm{N}_{2}$-fixing species (Pinus contorta and Dichanthium aristatum) has been shown to originate from atmospheric fixation by their $\mathrm{N}_{2}$ fixing neighbours (Alnus glutinosa and Gliricidia sepium) (Arnebrant et al. 1993; Daudin and Sierra 2008). Nonetheless, as far as we are aware no study has considered the impact of elevated atmospheric $\mathrm{CO}_{2}$ on the transfer of fixed $\mathrm{N}$ between $\mathrm{N}_{2}$-fixing and non- $\mathrm{N}_{2}$-fixing trees.

The measurement of the relative abundance of the two most abundant stable isotopes of $\mathrm{N}$ $\left({ }^{14} \mathrm{~N}\right.$, which constitutes approximately $99.6 \%$ of all $\mathrm{N}$ and ${ }^{15} \mathrm{~N}$, which constitutes approximately $0.4 \%$ of all $\mathrm{N}$ ), provides a useful tool for investigating the $\mathrm{N}$ cycle. Some processes result in fractionation (i.e. the preferential movement or uptake of the heavier or lighter isotope) resulting in relative ${ }^{15} \mathrm{~N}$ enrichment (i.e. an increase in the proportion of ${ }^{15} \mathrm{~N}$ and therefore $\delta^{15} \mathrm{~N}$ ) or ${ }^{15} \mathrm{~N}$ depletion (i.e. a decrease in the amount of ${ }^{15} \mathrm{~N}$ and therefore $\delta^{15} \mathrm{~N}$ ). Thus, the $\delta^{15} \mathrm{~N}$ of a tree reflects the $\delta^{15} \mathrm{~N}$ of the $\mathrm{N}$ source(s) subject to any fractionation that occurs during movement from or to the tree, gains and losses of $\mathrm{N}$ and $\mathrm{N}$ pool mixing (Robinson 2001). As such changes in $\delta^{15} \mathrm{~N}$ can indicate changes in these components of forest N cycling (Emmett et al. 1998; Robinson 2001; BassiriRad et al. 2003). While these changes cannot necessarily be used to quantify specific differences in the $\mathrm{N}$ cycle, they can be used to 
identify areas that might be affected by any impacts on the $\mathrm{N}$ cycle. However, where two sources of $\mathrm{N}$ contribute to a pool, and the $\delta^{15} \mathrm{~N}$ of each is distinctly different, the $\delta^{15} \mathrm{~N}$ of the sources and pool can be used to estimate the relative contribution of each source. This method is well established for measuring the contribution of atmospherically fixed $\mathrm{N}$ to the total $\mathrm{N}$ content of plants (Boddey et al. 2000; Unkovich et al. 2008).

In this study we measured the proportion of $\mathrm{N}$ that was derived from atmospheric fixation (\%Ndfa) for the $\mathrm{N}_{2}$-fixing tree A. glutinosa growing in monoculture or in a mixture with Betula pendula and Fagus sylvatica in a FACE study (BangorFACE). Previous monitoring showed no significant effect of $\mathrm{CO}_{2}$ on biomass except for an increase in the biomass of $A$. glutionsa growing in monoculture (Smith 2010). Specifically, we aimed to address the hypotheses that 1: $\mathrm{N}_{2}$ fixation in A. glutinosa will increase in response to increased atmospheric $\mathrm{CO}_{2}$ concentrations, when growing in monoculture, 2: the impact of elevated $\mathrm{CO}_{2}$ on $\mathrm{N}_{2}$ fixation in A. glutinosa is the same in mixture and in monoculture and 3: the impacts of elevated $\mathrm{CO}_{2}$ on $\mathrm{N}$ cycling will be evident in a decrease in leaf $\delta^{15} \mathrm{~N}$ and in the soil-leaf enrichment factor (EF), and that these impacts will not differ between mixed and single species stands.

Materials and Methods

Site description and sampling methods

The BangorFACE site is located on a north west facing shallow slope of approximately $1-2^{\circ}$ on a deltaic fan at 13-18 m a.s.l. at the Henfaes research station of the University of Wales, Bangor (UK Grid ref: SH655730; Lat. 53.23, Long. -4.02). The climate is hyperoceanic, with annual rainfall of about $1000 \mathrm{~mm}$. Soils are fine loamy brown earth over gravel (Rheidol series) and are 63\% sand, 28\% silt and 9\% clay (Teklehaimanot and Sinclair 1993). Water 
table depth ranges between 1-6 m. Total wet and dry $\mathrm{N}$ deposition is estimated to be $27.9 \mathrm{~kg}$

The FACE plots are located within a wider forest plantation, which is continuous over a total area of 2.36 ha and is spread over two fields that are within $20 \mathrm{~m}$ of each other. This plantation was established at the same time as the FACE plots in March 2004 and was planted with a mixture of tree species (Anus glutinosa (L.) Gaertn., Betula pendula Roth., Fagus sylvatica L., Fraxinus excelsior, Acer pseudoplatinus, Castanea satvia and Quercus robur) and has been subject to no human disturbance since planting. Four FACE and four ambient plots were randomly located within this plantation, evenly split between the two fields, in a complete replicated block design. These experimental plots were $8 \mathrm{~m}$ in diameter, and planted at $80 \mathrm{~cm}$ spacing in a hexagonal design (approx. 18000 stems ha $^{-1}$ ) with 2 year old B. pendula, A. glutinosa and F. sylvatica. These species are native to the UK, cover a range of ecological and life history traits, and can grow together in semi-natural systems. At planting the trees were approximately $60 \mathrm{~cm}$ in height, when the $\mathrm{CO}_{2}$ system was turned on in 2005 they were respectively $140.71 \pm 8.1,116.82 \pm 6.3$ and $51.17 \pm 2.63 \mathrm{~cm}$ in height, at the time of leaf collection in 2008 canopy closure had occurred and the trees were on average $463.21 \pm 10.8,487.83 \pm 9.7$ and $196.25 \pm 7.2 \mathrm{~cm}$ in height respectively. The plots are surrounded by a $10 \mathrm{~m}$ buffer strip of $B$. pendula, A. glutinosa and F. sylvatica planted at the same density. The planting pattern within these plots created seven sub-plots with mixtures containing one, two or three species. For the purpose of this study, trees in four of these subplots were measured: three single species sub-plots and the sub-plot containing a mixture of all three species. These three treatments $\left(\mathrm{CO}_{2}\right.$, mixture/monoculture and species) are combined in a $2 \times 2 \times 3$ full factorial design resulting in 12 treatment combinations.

177 Carbon dioxide enrichment was achieved using pure $\mathrm{CO}_{2}$ from natural gas injected through 178 laser-drilled holes in tubing mounted on eight masts (Miglietta et al. 2001). The elevated $\mathrm{CO}_{2}$ 
concentrations were measured at 1 minute intervals and were within $30 \%$ deviation from the pre-set target concentration of $200 \mathrm{ppm}$ above ambient (ambient $=380 \mathrm{ppm}$, elevated $=580$ ppm) $\mathrm{CO}_{2}$ for $75-79 \%$ of the time during the photosynthetically active part of 2005-2008 (i.e. from spring bud-burst until autumn leaf abscission).

Total tree biomass (aboveground + belowground) in the plots was monitored over the course of the experiment using stem diameters and site specific allometric equations and is reported in Smith (2011). At the conclusion of the experiment in 2008 the only statistically significant impact of elevated $\mathrm{CO}_{2}$ was a $32 \%$ increase in total A. glutinosa biomass under elevated $\mathrm{CO}_{2}$ when growing in monoculture. There was no significant impact of elevated $\mathrm{CO}_{2}$ on any of the other species growing in monoculture or any of the species growing in mixture. Alnus glutionsa and $B$. pendula growing in mixture were significantly larger than when growing in monoculture, whereas F. sylvatica were smaller when growing in mixture (Smith 2011).

Measurements and leaf samples were taken in 2008, when the trees were approximately 6.5 years old, after 4 growing seasons of the $\mathrm{CO}_{2}$ treatment. Three individual trees were sampled from each species growing in monoculture and in mixture (i.e. $n=3$ trees per species per subplot, 18 trees per ring), in each of the 4 ambient and elevated FACE rings (total $n=144$ trees).

The trees to be sampled were chosen from those in the centre of each sub-plot (i.e. monoculture or mixture), from where they were selected at random. For trees growing in monoculture all 6 nearest neighbours (accounting for the hexagonal planting design) were the same species. For trees growing in mixture the 6 nearest neighbours contained at least one individual from each of the three species. For each tree, diameter of the main stem (stem diameter at $22.5 \mathrm{~cm}$ height) and height were measured. Additionally, leaf samples ( $n=5$ per tree) were taken. A stratified random sample of leaves was taken from the canopy of each tree to ensure that the leaf sample was representative. This is because $\delta^{15} \mathrm{~N}$ of tree leaves may be dependent on their position in the canopy (Domenach et al. 1989). The vertical extent of 
the canopy was measured using a telescopic height pole. One leaf was removed from each of

205

206

207

208

209

210

211

212

213

214

215

216

217

218

219

220

221

222

223

224 five equal size vertical strata within the canopy, covering the entire depth of the canopy. Leaf samples and tree measurements were made in late summer (16- to 20-Aug-2008) when N content was assumed to be at its peak. Soil samples were obtained from each of the four stands in each ring during root coring in Jan-2008. An eight $\mathrm{cm}$ auger corer was used to collect samples at three depths: 0-10, 10-20 and 20-30 cm.

The leaves were scanned into a computer using a flatbed scanner and the area was measured using ImageJ image analysis software (Abramoff et al. 2004). The leaves were then dried at $80^{\circ} \mathrm{C}$ for 72 hours and weighed. They were then milled to a fine powder in a ball mill and the $\delta^{15} \mathrm{~N}$ was analysed using a Carlo-Erba elemental analyser linked to a Dennis Leigh Technologies IRMS. Leaf $\mathrm{N}$ concentration was then calculated on an area $\left(\mathrm{N}_{\mathrm{AREA}}\right)$ and mass $\left(\mathrm{N}_{\text {MASS }}\right)$ basis. Soil cores were coarse sieved $(8 \mathrm{~mm})$ to remove roots and large stones. A subsample of the soil from each depth was taken, dried at $80^{\circ} \mathrm{C}$ overnight, sieved $<2 \mathrm{~mm}$ and ground to a fine powder. $\delta^{15} \mathrm{~N}$ was analysed using a Finnigan MAT Delta Plus XL continuous flow mass spectrometer. The relative abundance of ${ }^{14} \mathrm{~N}$ and ${ }^{15} \mathrm{~N}$ is expressed using the standard delta $(\delta)$ notation for stable isotopes. $\delta$ is the relative difference in the ratio of the two forms of $\mathrm{N}$ in comparison to that of air and is expressed on a per mil basis $(\%)\left(\delta^{15} \mathrm{~N}\right.$ of air is therefore by definition $0 \%)$. As such, $\delta=\left(\mathrm{R}_{\text {sample }} / \mathrm{R}_{\text {reference }}\right)-1 \times 1000$, and $\mathrm{R}={ }^{15} \mathrm{~N}:{ }^{14} \mathrm{~N}$. Data are reported with respect to $\mathrm{N}$ in air.

\section{Natural abundance stable isotope method}

We measured the contribution of $\mathrm{N}$ derived from the atmosphere $\left(\mathrm{N}_{\mathrm{dfa}}\right)$ to the $\mathrm{N}$ budget of the A. glutinosa trees using the natural abundance stable isotope method (after Shearer and Kohl 1986). This method was used because it was not possible to add labelled $\mathrm{N}$ to the site due to the potential for disturbing the $\mathrm{N}$ cycle and because the site is used for ongoing long-term 
studies. The contribution of $\mathrm{N}_{\mathrm{dfa}}$ to the $\mathrm{N}$ budget of $\mathrm{N}_{2}$-fixing plants can be estimated by comparing $\delta^{15} \mathrm{~N}$ of the $\mathrm{N}_{2}$-fixing plant with non- $\mathrm{N}_{2}$-fixing reference plants (representing $\delta^{15} \mathrm{~N}$ of the $\mathrm{N}_{2}$-fixing species when obtaining all $\mathrm{N}$ from the soil) and $\mathrm{N}_{2}$-fixing species grown with no root $\mathrm{N}$ addition (Boddey et al. 2000). In this study we compared $\delta^{15} \mathrm{~N}$ of A. glutinosa with that of B. pendula and F. sylvatica growing in monoculture.

The ${ }^{15} \mathrm{~N}$ natural abundance method provides quantification of $\mathrm{N}_{2}$ fixation when rates of $\mathrm{N}_{2}$ fixation are high and when the plants are demonstrably fixing $\mathrm{N}_{2}$ (Unkovich et al. 2008). Consistently reduced $\delta^{15} \mathrm{~N}$ and root nodulation observed in roots excised for other studies (Smith 2011) demonstrates $\mathrm{N}_{2}$ fixation of A. glutinosa in this study. $\delta^{15} \mathrm{~N}$ depletion in $A$. glutinosa compared to the reference plants indicates high $\mathrm{N}_{2}$ fixation rates. The value of $\mathrm{B}$ $\left(\delta^{15} \mathrm{~N}\right.$ of $A$. glutinosa trees with access to atmospheric $\mathrm{N}$ only) used was $4.5 \%$ lower than the mean for the reference plants. While below the minimum value of 5\% recommended by Högberg (1997), there is clear and consistent separation between $\delta^{15} \mathrm{~N}$ of the reference trees and A. glutionsa.

Boddey et al. (2000) and Unkovich et al. (2008) suggest that more than one reference species should be used and that they should be of a similar life form, size, duration of growth and that they should have no access to fixed $\mathrm{N}_{2}$. We used two reference species, and both were trees planted at the same time at the A. glutionsa with similar rooting depths, though F. sylvatica roots tend to be shallower (Atkinson 1992; Claessens et al. 2010; Bakker et al. 2008). In addition, reference plants growing in ambient $\mathrm{CO}_{2}$ concentrations were used to calculate $\% \mathrm{~N}_{\mathrm{dfa}}$ and $\mathrm{N}_{\mathrm{dfa}}$ for A. glutinosa growing in ambient $\mathrm{CO}_{2}$ concentrations. Reference plants growing in elevated $\mathrm{CO}_{2}$ concentrations were used to calculate $\% \mathrm{~N}_{\mathrm{dfa}}$ and $\mathrm{N}_{\mathrm{dfa}}$ of A. glutinosa growing in elevated $\mathrm{CO}_{2}$. Furthermore, the calculations of $\mathrm{N}_{\mathrm{dfa}}$ and $\% \mathrm{~N}_{\mathrm{dfa}}$ using each reference species are similar. There is good evidence that no fixed $\mathrm{N}$ is incorporated into the references trees. The $\delta^{15} \mathrm{~N}$ of $B$. pendula leaves from a larger $(20 \times 20 \mathrm{~m})$ single species stand 
in the same plantation was identical $(2.2 \%)$ to that of $B$. pendula in monoculture in the closest study ring $30 \mathrm{~m}$ away.

255

256

257

258

259

260

261

262

263

264

265

266

267

Similarity in $\delta^{15} \mathrm{~N}$ of the sources of all three species and in fractionation within the trees is assumed. The broad similarities of $\delta^{15} \mathrm{~N}$ in F. sylvatica and B. pendula leaves suggests that this assumption holds (the difference in $\delta^{15} \mathrm{~N}$ between $F$. sylvatica and B. pendula is very small $(0.5 \%)$ compared to the mean difference between these reference plants and $A$. glutinosa (2.7\%o)). Leaf $\delta^{15} \mathrm{~N}$ did not differ from weighted whole tree $\delta^{15} \mathrm{~N}$ for any of the three species (details in supplementary information). Thus, the use of leaf samples as representative of whole tree $\delta^{15} \mathrm{~N}$ is supported. We therefore consider the quantification to remain robust.

\section{Data analysis}

The proportion of plant $\mathrm{N}$ derived from $\mathrm{N}_{2}$ fixation $\left(\% \mathrm{~N}_{\mathrm{dfa}}\right)$ was calculated from the $\delta^{15} \mathrm{~N}$ of the leaves using a simple one-isotope, two-source, end-member mixing model as follows (after Shearer and Kohl 1986):

Equation 1: $\% \mathrm{~N}_{\mathrm{dfa}}=\frac{\left(\delta^{15} \mathrm{~N}_{\text {REF }}-\delta^{-15} \mathrm{~N}_{\text {TBEE }}\right)}{\left(\delta^{15} \mathrm{~N}_{\mathrm{REF}}-\mathrm{B}\right)} \times 100$ where $\% \mathrm{Ndfa}$ is the percentage of leaf- $\mathrm{N}$ fixed from the atmosphere, $\delta^{15} \mathrm{~N}_{\mathrm{REF}}$ is the $\delta^{15} \mathrm{~N}$ of trees for which the only source of $\mathrm{N}$ is through soil uptake (in this study the mean $\delta^{15} \mathrm{~N}$ of leaves on F. sylvatica and B. pendula growing in monoculture in the same ring), $\delta^{15} \mathrm{~N}_{\text {TREE }}$ is the $\delta^{15} \mathrm{~N}$ of the tree of interest and $\mathrm{B}$ is the $\delta^{15} \mathrm{~N}$ of trees for which the only source of $\mathrm{N}$ is derived from atmospheric fixation, B of $-1.9 \%$ was used, based on nodulated A. glutinosa plants growing in an $\mathrm{N}$-free medium, as determined by Domenach et al. (1989). \%Ndfa and Ndfa were calculated separately using F. sylvatica or B. pendula as reference plants and using the mean value for the two species. 
276 To isolate leaf $\delta^{15} \mathrm{~N}$ from differences in bulk soil $\delta^{15} \mathrm{~N}$, a soil-leaf $\mathrm{N}$ enrichment factor (EF)

277 was calculated for the two non- $\mathrm{N}_{2}$-fixing trees. The soil-leaf EF measures the relative ${ }^{15} \mathrm{~N}$ depletion/enrichment from bulk soil to leaf. Thus it provides a sensitive qualitative measure

279 of changes in $\mathrm{N}$ cycling in the plant-soil system where patterns in leaf $\delta^{15} \mathrm{~N}$ might be less sensitive due to changes in bulk soil $\delta^{15} \mathrm{~N}$ (Amundson et al. 2003; Kahmen et al. 2008). EF was calculated as follows for each tree (after Garten et al. 2007):

Equation 2: $E F=\delta^{15} \mathrm{~N}_{\text {SOIL }}-\delta^{15} \mathrm{~N}_{\mathrm{LEAF}}$

where $\delta^{15} \mathrm{~N}_{\text {SOIL }}$ is the overall mean $\delta^{15} \mathrm{~N}$ of soil from $0-10,10-20$ and $20-30 \mathrm{~cm}$ depth and $\delta^{15} \mathrm{~N}_{\mathrm{LEAF}}$ is the overall mean $\delta^{15} \mathrm{~N}$ of all leaves taken from throughout the canopy.

Stem diameter at $22.5 \mathrm{~cm}$ of each tree was used to estimate total leaf mass using allometric equations based on trees harvested in 2006 from the buffer zone around the FACE and ambient rings (details in supplementary information). Estimates of total leaf mass were combined with measurements of leaf $\mathrm{N}$ to calculate the total amount of leaf $\mathrm{N}\left(\mathrm{N}_{\mathrm{TOTAL}}\right)$, the total amount of leaf $\mathrm{N}$ derived from the atmosphere $\left(\mathrm{N}_{\mathrm{dfa}}\right)$ and the soil $\left(\mathrm{N}_{\mathrm{dfs}}\right)$ on a per tree basis.

The measurements for the five leaf samples per tree were averaged over the whole tree to give one mean value per tree. These tree level data were analysed as a split-split-plot design ANOVA in SPSS (SPSS Inc., 2008) using the general linear model (GLM). Individual rings (Ring) were treated as 'plots' and were nested within $\mathrm{CO}_{2}(\mathrm{CO} 2)$ treatments.

Mixture/monoculture (MixMon) was treated as a sub-plot within ring and species was nested within mixture/monoculture. The model used was: $\mathrm{CO} 2+\operatorname{Ring}(\mathrm{CO} 2)+$ MixMon + Species + MixMon $\times \operatorname{Ring}(\mathrm{CO} 2)+$ Species $\times \operatorname{Ring}(\mathrm{CO} 2)+\mathrm{CO} 2 \times$ Species $+\mathrm{CO} 2 \times$ MixMon + Species $\times$ MixMon + Species $\times$ MixMon $\times$ Ring $(\mathrm{CO} 2)+\mathrm{CO} 2 \times$ Species $\times$ MixMon. Ndfa and $\% \mathrm{~N}_{\mathrm{dfa}}$ were only analysed for A. glutinosa, using the same model but with the terms containing 
300

'Species' omitted. Soil $\delta^{15} \mathrm{~N}$ data were analysed using a repeated measures GLM. Where the F-test was significant, Fisher's protected LSD was used for post-hoc multiple comparisons. Betula pendula and F. sylvatica trees had different numbers of A. glutinosa neighbours when growing in mixture (between 1-4). The impact of the number of A. glutinosa neighbours on $\delta^{15} \mathrm{~N}$ of leaves of $B$. pendula and F. sylvatica leaves was tested using a Kruskal-Wallis test, because it was difficult to ascertain compliance with the assumptions of ANOVA due to the uneven sample sizes. Betula pendula and F. sylvatica in monoculture were included as a 'zero A. glutinosa neighbours' group. Where appropriate data were $\log _{10}$ transformed to conform to the assumptions of normality and heteroscedacity. The small number of replicates for $\mathrm{CO}_{2}$ treatment increases the risk of a type II error so $\alpha$ of 0.1 was used. While this increases the risk of a type I error this was considered an acceptable trade-off.

\section{Results}

Leaf $\delta^{15} \mathrm{~N}$ differed significantly between species when growing in monoculture with $A$. glutinosa considerably lower than B. pendula which was slightly lower than F. sylvatica (Table 1, Fig. 1a). When compared with A. glutinosa across both $\mathrm{CO}_{2}$ treatments, B. pendula and F. sylvatica were relatively ${ }^{15} \mathrm{~N}$ enriched, by $2.5 \%$ and $2.9 \%$ respectively. The leaves of all species were ${ }^{15} \mathrm{~N}$ depleted under elevated $\mathrm{CO}_{2}$, by on average $0.4 \%$ compared to those in ambient $\mathrm{CO}_{2}$, but this effect was only statistically significant for $F$. sylvatica (A. glutinosa $=$ $0.3 \%$, B. pendula $=0.1 \%$, F. sylvatica $=0.8 \%$; Fig 1a, Table $1, \mathrm{CO}_{2}$ effect and $\mathrm{CO}_{2} \times$ Species interaction). Species composition had a significant impact on $\delta^{15} \mathrm{~N}$ values of trees grown in mixture, which were significantly ${ }^{15} \mathrm{~N}$ depleted compared to those in monoculture (Fig. 1a, Table1). Furthermore, the leaves of the non- $\mathrm{N}_{2}$-fixing species became less ${ }^{15} \mathrm{~N}$ enriched with increasing numbers of A. glutinosa neighbours (Fig. 2). Though when considering the two species separately this effect was less clear. 
324 Soil was consistently ${ }^{15} \mathrm{~N}$ enriched under elevated $\mathrm{CO}_{2}$ across stands, by on average $0.4 \%$,

325 but became significantly less ${ }^{15} \mathrm{~N}$ enriched with increasing depth (Fig. 3). However, soil $\delta^{15} \mathrm{~N}$

326 did not differ significantly between stands (data not shown). Overall the soil-leaf ${ }^{15} \mathrm{~N}$

327 enrichment factor (EF) for trees growing in elevated $\mathrm{CO}_{2}$ was more negative than those in

328 ambient $\mathrm{CO}_{2}$ by $0.8 \%$, reflecting increased soil-leaf ${ }^{15} \mathrm{~N}$ depletion, though this $\mathrm{CO}_{2}$ effect

329 was largest and only statistically significant for F. sylvatica (Table 1, Fig. 1b). Overall, there

330 was no significant difference in EF between F. sylvatica and B. pendula (Fisher's LSD,

$331 P>0.05)$.

The total amount of leaf $\mathrm{N}$ in the trees was calculated by multiplying leaf $\mathrm{N}$ concentration

( $\mathrm{N}_{\text {MASS }}$ ) by estimated leaf mass (from site specific allometric equations). Total leaf $\mathrm{N}$ differed between species and followed the pattern of tree biomass (measured in the same study by Smith, 2011). Alnus glutinosa and B. pendula contained the same amount of N, with both of these species containing a far greater amount of $\mathrm{N}$ than $\mathrm{F}$. sylvatica. Elevated $\mathrm{CO}_{2}$ increased the total amount of leaf $\mathrm{N}$ in all trees in all treatments, by an average of $14 \%$ (Table 1, Fig. 4a), but this $\mathrm{CO}_{2}$ effect was not statistically significant. Furthermore, total leaf $\mathrm{N}$ differed for trees growing in mixture or monoculture, due to a large, significant difference between total leaf $\mathrm{N}$ of $A$. glutinosa in mixture and in monoculture (mixture $=20.0 \pm 1.6$ g. $\operatorname{tree}^{-1}$, monoculture $=12.8 \pm 1.6$ g. tree ${ }^{-1}$, Fisher's LSD $P<0.05$ ). There was no difference between the other two species growing in mixture and monoculture. The source of this leaf $\mathrm{N}$ varied between species. There was significantly less soil-derived $\mathrm{N}$ in the leaves of A. glutinosa than those of B. pendula, with that of F. sylvatica being considerably lower than both (Fig. 4a, Table 2). The high total leaf $\mathrm{N}$ in A. glutinosa was due to the contribution of fixed $\mathrm{N}$. measures of leaf $\mathrm{N}$ concentration there were differences between species, with leaf $\mathrm{N}$ concentration of A. glutinosa and B. pendula showing no significant difference and both these 
species having higher leaf $\mathrm{N}$ concentrations than did F. sylvatica. The differences were greater when trees were growing in mixture compared to when species differences were compared for trees growing in monoculture. However, when considering responses to elevated $\mathrm{CO}_{2}, \mathrm{~N}_{\text {AREA }}$ and $\mathrm{N}_{\text {MASS }}$ were affected differently. There was no impact of elevated $\mathrm{CO}_{2}$ on $\mathrm{N}_{\text {MASS }}$. However, elevated $\mathrm{CO}_{2}$ reduced $\mathrm{N}_{\mathrm{AREA}}$ by an average of $5.3 \%$. This reduction was consistent for all species.

When $\delta^{15} \mathrm{~N}$ was used to estimate the amount of fixed $\mathrm{N}$ in A. glutinosa the trees gained on average $10.5 \pm 0.9$ g. tree ${ }^{-1}$ of $\mathrm{N}$ from fixation. For trees growing in mixture there was a trend towards increased $\mathrm{N}_{\mathrm{dfa}}$ under elevated $\mathrm{CO}_{2}$, with A. glutinosa trees obtaining $46 \%$ more $\mathrm{N}$ from fixation than under ambient atmospheric $\mathrm{CO}_{2}$ (Fig. 4a, Table 2, $\mathrm{CO}_{2} \times$ 'MixMon', $P=0.15$ ). While this effect is not statistically significant, the magnitude of the effect is likely to be biologically significant. As a result of this increase in mixture there was a significant effect of species composition on $\mathrm{N}_{\mathrm{dfa}}$ but no overall effect of $\mathrm{CO}_{2}$ treatment (Table 2). This fixed $\mathrm{N}$ contributed on average $62.1 \pm 0.1 \%$ of the total $\mathrm{N}$ in A. glutinosa leaves. As a result of the increased $\mathrm{N}_{2}$ fixation under elevated $\mathrm{CO}_{2}$ for trees in mixture, the percentage contribution of fixed $\mathrm{N}$ increased by $6.9 \%$ for these trees compared to those in ambient $\mathrm{CO}_{2}(68.3 \%$ compared to $61.4 \%$, Fig. 5). This effect resulted in a significant impact of species composition on $\% \mathrm{~N}_{\mathrm{dfa}}$ and a trend towards an interaction (though not statistically significant) between species composition and the impact of elevated $\mathrm{CO}_{2}$, but no significant effect of $\mathrm{CO}_{2}$ overall (Table 2).

\section{Discussion}

Our study is the first to measure $\mathrm{N}_{2}$ fixation in a tree species in FACE conditions. The observed increased growth of A. glutinosa in monoculture under elevated $\mathrm{CO}_{2}$ was not supported by increased $\mathrm{N}_{2}$ fixation, either on an absolute $\left(\mathrm{N}_{\mathrm{dfa}}\right)$ or relative $\left(\% \mathrm{~N}_{\mathrm{dfa}}\right)$ basis. Thus 
we cannot support our first hypotheses, that $\mathrm{N}_{2}$ fixation in A. glutinosa will increase in response to increased atmospheric $\mathrm{CO}_{2}$ concentrations, when growing in monoculture. Instead elevated $\mathrm{CO}_{2}$ resulted in a slight (but not statistically significant) increase in root $\mathrm{N}$ uptake and decrease in leaf $\mathrm{N}$ concentration (thought this was only statistically significant on an area basis). Previous studies have shown that in some circumstances $\mathrm{N}_{2}$ fixation increases to support higher growth rates under elevated $\mathrm{CO}_{2}$. Norby (1987) and Vogel et al. (1997) found that $A$. glutionsa trees growing in elevated $\mathrm{CO}_{2}$ were larger and fixed more $\mathrm{N}$, but that this was due to their larger size rather than an increase in the rate of $\mathrm{N}_{2}$ fixation per se.

However, Temperton et al. (2003) grew A. glutionsa trees in more realistic field conditions and found that elevated $\mathrm{CO}_{2}$ had no statistically significant impact on $\mathrm{N}_{2}$ fixation. Our study, with the findings of Temperton et al. (2003) suggests that when growing in single species stands, in 'real world' conditions A. glutionsa does not support $\mathrm{CO}_{2}$ induced growth increase with $\mathrm{N}_{2}$ fixation, but rather with an increase in root $\mathrm{N}$ uptake and nitrogen use efficiency. However, it is possible that over longer periods of time this might change.

Our study suggests fundamental differences in forest ecosystem function in mixed stands compared to single species stands. These differences have impacted on the response of $\mathrm{N}_{2}$ fixation to elevated $\mathrm{CO}_{2}$. Thus we cannot support our second hypothesis, that the impact of elevated $\mathrm{CO}_{2}$ on $\mathrm{N}_{2}$ fixation in A. glutinosa is the same in mixture and in monoculture. As such, our findings differ from patterns found in other systems. For example, Lee et al. (2003) found that $\mathrm{N}_{2}$ fixation in Lupinus sp. was increased by elevated atmospheric $\mathrm{CO}_{2}$ in both monoculture and in a mixed grassland system. We provide some evidence that $\mathrm{N}_{2}$ fixation might have been stimulated by elevated $\mathrm{CO}_{2}$ for A. glutionsa trees growing in mixture, despite there being no statistically significant impact of $\mathrm{CO}_{2}$ on tree biomass. There were large differences in growth rate, $\mathrm{N}$ uptake and $\mathrm{N}_{2}$ fixation for $A$. glutinosa trees growing in mixture, compared to those growing in monoculture, which might account for the difference 
in response. Biomass of $A$. glutionsa trees in mixture was approximately $50 \%$ greater than that of those in monoculture (the same trees measured by Smith 2011), with a commensurate $56 \%$ increase in total leaf $\mathrm{N}$ and nearly double the amount of fixed $\mathrm{N}$. Decreased $\delta^{15} \mathrm{~N}$ of the

401

402

403

404

405

406

407

408

409

410

411

412

413

414

415

416

417

418

419

420 trees when species are growing in mixture also suggests that $\mathrm{N}$ cycling is different in mixture than in monoculture. This might be due to increased ecosystem resource utilisation when more trees species are present, for example through niche differentiation. These differences may result from impacts on any part of the N-cycle, for example, inputs of fixed $\mathrm{N}_{2}$, mycorrhizae (e.g. Hobbie et al. 2000) or litter inputs and decomposition (e.g. Zak et al. 2003) all of which might be affected by changes in atmospheric $\mathrm{CO}_{2}$.

When growing in mixture with A. glutinosa, F. sylvatica and B. pendula leaves were less enriched in ${ }^{15} \mathrm{~N}$ compared to the leaves of these species growing in monoculture.

Furthermore, leaves of $F$. sylvatica and B. pendula with greater numbers of $A$. glutinosa trees as direct neighbours were significantly depleted in ${ }^{15} \mathrm{~N}$ compared to those with fewer. It seems likely that these changes in $\delta^{15} \mathrm{~N}$ are explained by the incorporation of fixed $\mathrm{N}_{2}$ into these tissues. This is consistent with other studies where $\delta^{15} \mathrm{~N}$ of $\mathrm{N}_{2}$-fixing trees has been compared with co-occurring non- $\mathrm{N}_{2}$-fixing species (e.g. Daudin and Sierra 2008) and where the transfer of fixed $\mathrm{N}_{2}$ specifically has been measured. For example the contribution of transferred $\mathrm{N}$ to total $\mathrm{N}$ was on average 5-15\% (Arnebrant et al. 1993) and 1.3-3\% (Ekblad and Huss-Danell 1995) between A. glutinosa and P. contorta and A. incana and P. sylvestris respectively. These inputs of fixed $\mathrm{N}_{2}$ do not translate into differences in $\delta^{15} \mathrm{~N}$ of the soil in stands containing A. glutinosa. This suggests that inputs of fixed $\mathrm{N}_{2}$ are small relative to the ecosystem $\mathrm{N}$ pool, or that little fixed $\mathrm{N}_{2}$ makes its way into the soil $\mathrm{N}$ pool, possibly due to a tightly coupled leaf-soil-plant $\mathrm{N}$ cycle. Additionally, the clear impact of A. glutinosa on $\delta^{15} \mathrm{~N}$ of these species in mixture highlights the importance of choosing reference plants that are not growing in close proximity to $\mathrm{N}_{2}$-fixing plants. 
423 There is clear evidence that the A. glutinosa trees in this study obtained a significant

424 proportion of their $\mathrm{N}$ from biological fixation. The leaves of A. glutinosa trees were ${ }^{15} \mathrm{~N}$

425

426

427

428

429

430

431

432 depleted relative to those of F. sylvatica or B. pendula in the same plots. This suggests that a large proportion (approximately 62\%) of the $\mathrm{N}$ contained in the trees was fixed from the atmosphere. This is consistent with previous studies of Alnus. For example, (Sanborn et al. 2002) found that $A$. viridis fixed $10-15 \mathrm{~kg} \mathrm{~N} \mathrm{ha}^{-1} \mathrm{year}^{-1}$ and that this contributed $>90 \%$ of the total N content of these trees. Ekblad and Huss-Danell (1995) found that for A. incana fixed $\mathrm{N}_{2}$ contributed between $45 \%$ and $90 \%$ of total $\mathrm{N}$. As a result of this uptake of fixed $\mathrm{N}_{2}, A$. glutinosa in our study relied on root derived $\mathrm{N}$ to a far smaller extent than did the non- $\mathrm{N}_{2}-$ fixing species.

Ecosystem C and N pools are tightly linked (Chen and Coops 2009). Therefore, forest responses to elevated atmospheric $\mathrm{CO}_{2}$ are linked to ecosystem $\mathrm{N}$ availability and cycling (Oren et al. 2001; Ainsworth and Long 2005; Norby and Iversen, 2006; Reich et al. 2006b; Zak et al. 2006; Finzi et al. 2007). For non- $\mathrm{N}_{2}$-fixing trees leaf $\delta^{15} \mathrm{~N}$ is determined by source (i.e. soil) $\delta^{15} \mathrm{~N}$ subject to any fractionation that occurs during uptake or within the tree. Thus, changes in leaf $\delta^{15} \mathrm{~N}$ might reflect changes in bulk soil $\delta^{15} \mathrm{~N}$, differential uptake of different forms of $\mathrm{N}$ (with different $\delta^{15} \mathrm{~N}$ signatures) or changes in fractionation during uptake. The impact of elevated $\mathrm{CO}_{2}$ on $\mathrm{N}$ cycling can therefore be reflected in leaf $\delta^{15} \mathrm{~N}$, with a tendency towards a decrease in $\delta^{15} \mathrm{~N}$ when $\mathrm{CO}_{2}$ is elevated for both woody and herbaceous plants (BassiriRad et al. 2003).

The relative ${ }^{15} \mathrm{~N}$ depletion by $0.4 \%$ of tree leaves under elevated $\mathrm{CO}_{2}$ in our study was matched by relative enrichment of soil by $0.4 \%$. Thus the $\delta^{15} \mathrm{~N}$ of the plant-soil system appears to have remained constant, but elevated $\mathrm{CO}_{2}$ appears to have resulted in a change in distribution of ${ }^{15} \mathrm{~N}$ from plant to soil. The use of a soil-leaf enrichment factor (EF) quantifies this change in ${ }^{15} \mathrm{~N}$ distribution. The EF for the trees in our study was consistently lower by on 
average $0.8 \%$ under elevated $\mathrm{CO}_{2}$ indicating a consistent change in the distribution of ${ }^{15} \mathrm{~N}$ between soil and leaf. The relative leaf ${ }^{15} \mathrm{~N}$ depletion and associated changes in the soil-plant

${ }^{15} \mathrm{~N}$ enrichment factor (EF) for trees growing under elevated $\mathrm{CO}_{2}$ follow the trend for identified by Bassirirad et al. (2003). The opposing response of soil and leaves suggests that changes in leaf $\delta^{15} \mathrm{~N}$ are not due to changes in bulk soil $\delta^{15} \mathrm{~N}$, or internal fractionation. Furthermore, the largest ${ }^{15} \mathrm{~N}$ depletion was in one of the non- $\mathrm{N}_{2}$-fixing trees suggesting that the effect is not due to atmospheric $\mathrm{N}_{2}$ fixation. This is good evidence to support our third hypothesis, that the impacts of elevated $\mathrm{CO}_{2}$ on $\mathrm{N}$ cycling will be evident in a decrease in leaf $\delta^{15} \mathrm{~N}$ and in the soil-leaf enrichment factor (EF), and that these impacts will not differ between mixed and single species stands. A strong candidate for the observed ${ }^{15} \mathrm{~N}$ depletion is increased reliance on mycorrhizal derived $\mathrm{N}$, which tends to be ${ }^{15} \mathrm{~N}$ depleted (Hobbie et al. 2000; Mayor et al. 2008). Increased mycorrhizal infection under elevated $\mathrm{CO}_{2}$ is regularly observed due to increased C supply to roots (e.g. Norby et al. 1987; Drigo et al. 2008). Alternatively, this relative depletion might be due to changes in uptake of relatively ${ }^{15} \mathrm{~N}$ enriched $\mathrm{NH}_{4}{ }^{+}$or relatively ${ }^{15} \mathrm{~N}$ depleted $\mathrm{NO}_{3}{ }^{-}$(Högberg 1997). This may be due to changes in the availability of these sources of $\mathrm{N}$ in the soil, or changes in uptake due to increasing $\mathrm{N}$ demand. More comprehensive and detailed measurement of the size and $\delta^{15} \mathrm{~N}$ of the various $\mathrm{N}$ pools would be required to better resolve this.

In conclusion, we found no evidence that increased growth of A. glutionsa when atmospheric $\mathrm{CO}_{2}$ was elevated was supported by increased $\mathrm{N}_{2}$ fixation. We found some evidence of biologically significant $\mathrm{CO}_{2}$ stimulation of $\mathrm{N}_{2}$ fixation in mixed stands, despite there being no statistically significant increase in growth. We found evidence of significant impacts of elevated $\mathrm{CO}_{2}$ on aspects of the $\mathrm{N}$ cycle, shown through differences in $\mathrm{N}_{2}$ fixation and $\delta^{15} \mathrm{~N}$. These impacts are dependent on the species composition of the forest. This study shows clear evidence that the $\mathrm{N}$-cycle in mixed species stands functions differently to that in single 
species stands. This is suggested by higher rates of $\mathrm{N}_{2}$ fixation in A. glutionsa, transfer of fixed $\mathrm{N}_{2}$ to non- $\mathrm{N}_{2}$-fixing species, changes in leaf $\delta^{15} \mathrm{~N}$ and large differences in tree $\mathrm{N}$ content. These different impacts have important consequences for how we consider the impacts of global environmental change and interactions with ecosystem function. Changes in atmospheric $\mathrm{CO}_{2}$ will occur concurrently with changes in plant community species composition due to this and other drivers of global environmental change (Badeck et al. 2001). Thus forest species compositions that exist when the atmospheric $\mathrm{CO}_{2}$ concentrations used in this and other studies are reached will be different to those at present. Our study shows that these changes can result in very real effects on forest $\mathrm{N}$ budgets and in the impact of elevated $\mathrm{CO}_{2}$ on these $\mathrm{N}$ budgets.

\section{Acknowledgements}

The development of the BangorFACE site was funded by the UK Science Research Infrastructure Fund (SRIF). We thank the Forestry Commission Wales and the Centre for Integrated Research in the Rural Environment (CIRRE) for support for the running costs. Many thanks to Michael Bambrick for help with access to samples and data. $\delta^{15} \mathrm{~N}$ analyses were performed by the Lancaster node of the Life Sciences Mass Spectrometry Facility (LSMSF) funded by the UK Natural Environment Research Council (NERC). The manuscript was considerably improved due to the thorough comments provided by two anonymous reviewers and Hormoz BassiriRad.

\section{References}

Abramoff MD, Magelhaes PJ, Ram SJ (2004) Image processing with ImageJ. Biophotonics International 11:36-42

Ainsworth EA, Long SP (2005) What have we learned from 15 years of free-air $\mathrm{CO}_{2}$ enrichment (FACE)? A meta-analytic review of the responses of photosynthesis, canopy properties and plant production to rising $\mathrm{CO}_{2}$. New Phytol. 165:351-71 
497 Amundson R, Austin AT, Schuur EAG, Yoo K, Matzek V, Kendall C, Uebersax A, Brenner

498 D, Baisden WT (2003) Global patterns of the isotopic composition of soil and plant nitrogen.

499 Global Biogeochem. Cycles 17:1031

500 APIS (2010) Air Pollution Information System. [online] available at: $<$ http://www.apis.ac.uk $>$ $501 \quad$ [accessed $21^{\text {st }}$ October 2011].

502 Arnebrant K, Ek H, Finlay RD, Söderström B (1993) Nitrogen translocation between Alnus 503 glutinosa (L.) Gaertn. seedlings inoculated with Frankia sp. and Pinus contorta (Doug.) ex 504 Loud seedlings connected by a common mycelium. New Phytol. 124:231-242

505 Atkinson MD (1992) Betula pendula Roth. (B. verrucosa Ehrh.) and B. pubescens Ehrh. J. 506 Ecol. 80:837-870

507 Bakker MR, Turpault MP, Huet S, Nys C (2008) Root distribution of Fagus sylvatica in a 508 chronosequence in western France. J. For. Res-Jpn 13:176-184

509 BassiriRad H, Constable JV, Lussenhop J, Kimball BA, Norby RJ, Oechel WC, Reich PB, 510 Schlesinger WH, Zitzer S, Sehtiya HL, Silim S (2003) Widespread foliage $\delta^{15} \mathrm{~N}$ depletion 511 under elevated $\mathrm{CO}_{2}$ : inferences for the nitrogen cycle. Glob. Change Bio. 9:1582-1590

512 Boddey RM, Peoples MB, Palmer B, Dart PJ (2000) Use of the ${ }^{15} \mathrm{~N}$ natural abundance 513 technique to quantify biological nitrogen fixation by woody perennials. Nutr. Cycl.

514 Agroecosys. 57:235-270

515 Bucher JB, Tarjan DP, Siegwolf RT, Saurer M, Blum H, Hendrey GR (1998) Growth of a 516 tree seedling community in response to elevated $\mathrm{CO}_{2}$ and nutrient supply. Chemosphere $517 \quad 36: 777-782$ 
Chen B, Coops, NC (2009) Understanding of coupled terrestrial carbon, nitrogen and water dynamics - an overview. Sensors 9:8624-8657

520 Classens H, Oosterbaan A, Savil P, Rondeux J (2010) A review of the characteristics of black alder (Alnus glutinosa (L.) (Gaertn.) and their implications for silvicultural practices.

522 Forestry, doi: 10.1093/forestry/cpp038

523 Cleveland CC, Townsend AR, Schimel DS, fisher H, Howarth, RW, Hedin LO, Perakis SS, 524 Latty EF, Von Fischer JC, Elseroad A, Wsson MF (1999) Global patterns of terrestrial biological nitrogen $\left(\mathrm{N}_{2}\right)$ fixation in natural ecosystems. Global Biogeochem. Cy. 13:623-645

Daudin D, Sierra J (2008) Spatial and temporal variation of below-ground N transfer from a leguminous tree to an associated grass in an agroforestry system. Agr. Ecosyst. Environ. $126: 275-280$

Domenach AM, Kurdali F, Bardin R (1989) Estimation of symbiotic dinitrogen fixation in alder forest by the method based on natural ${ }^{15} \mathrm{~N}$ abundance. Plant Soil 118:51-59

Drigo B, Kowalchuk GA, van Veen JA (2008) Climate change goes underground: effects of elevated atmospheric $\mathrm{CO} 2$ on microbial community structure and activities in the rhizosphere. Biol. Fert. Soils 44: 667-679

534 Ekblad A, Huss-Danell K (1995) Nitrogen fixation by Alnus incana and nitrogen transfer from A. incana to Pinus sylvestris influenced by macronutrients and ectomycorrhiza. New Phytol. 131:453-459

537 Emmett BA, Kjønaas OJ, Gundersen P, Koopmans C, Tietema A, Sleep D (1998) Natural 538 abundance of ${ }^{15} \mathrm{~N}$ in forests across a nitrogen deposition gradient. Forest Ecol. Manag. 101:9539 18 
540 Feng Z, Dyckmans J, Flessa H (2004) Effects of elevated carbon dioxide concentration on 541 growth and $\mathrm{N}_{2}$ fixation of young Robinia pseudocacia. Tree Physiol. 24:323-330

542 Finzi AC, Norby RJ, Calfapietra C, Gallet-Budynek A, Gielen B, Holmes WE, Hoosbeek 543 MR, Iversen CM, Jackson RB, Kubiske ME, Ledford J, Liberloo M, Oren R, Polle A, 544 Pritchard S, Zak DR, Shlesinger WH, Ceulemans R (2007) Increases in nitrogen uptake 545 rather than nitrogen-use efficiency support higher rates of temperate forest productivity under 546 elevated $\mathrm{CO}_{2}$. P. Natl. Acad. Sci. USA 104:14014-14019

547 Garten CT, Hanson PJ, Todd DE, Lu BB, Brice BJ (2007) Natural ${ }^{15} \mathrm{~N}$ - and ${ }^{13} \mathrm{C}$-abundance as 548 indicators of forest nitrogen status and soil carbon dynamics. In: Michener R, Lajtha K (eds) 549 Stable Isotopes in Ecology and Environmental Science. Blackwell Publishing Ltd, Oxford, $550 \quad$ UK, pp 61-82

551 Grace J (2004) Understanding and managing the global carbon cycle. J. Ecol. 92:189-202 He X, Critchley C, Bledsoe C (2003) Nitrogen Transfer Within and Between Plants Through 553 Common Mycorrhizal Networks (CMNs). Crit. Rev. Plant Sci. 22:531-567

554 Hobbie EA, Macko SA, Williams M (2000) Correlations between foliar $\delta^{15} \mathrm{~N}$ and nitrogen 555 concentrations may indicate plant mychorrhizal interactions. Oecologia 122:273-283.

556 Högberg P (1997) ${ }^{15} \mathrm{~N}$ natural abundance in soil-plant systems. New Phytol. 137:179-203

557 Hungate BA, Dijkstra P, Johnson DW, Hinkle CR, Drake BG (1999) Elevated $\mathrm{CO}_{2}$ increases 558 nitrogen fixation and decreases soil nitrogen mineralization in Florida scrub oak. Global 559 Change Biol. 5:781-789

560 Hungate BA, Stiling PD, Dijkstra P, Johnson DW, Ketterer ME, Hymus GJ, Hinkle CR, 561 Drake BG (2004) $\mathrm{CO}_{2}$ elicits long-term decline in nitrogen fixation. Science 304:1291 
563 Hutjes RWA, Ceulemans R, Schulze ED, Valentini R, Dolman AJ (2003) Europe's terrestrial

564 biosphere absorbs 7 to $12 \%$ of European anthropogenic $\mathrm{CO}_{2}$ emissions. Science 300:1538-

5651542

566 Kahmen A, Wanek W, Buchmann N (2008) Foliar $\delta^{15} \mathrm{~N}$ values characterize soil N cycling

567 and reflect nitrate or ammonium preference of plants along a temperate grassland gradient.

568 Oecologia 156:861-870

569 Körner C (2003) Carbon limitation in trees. J. Ecol. 91:4-17

570 Lee TD, Reich PB, Tjoelker MG (2003) Legume presence increases photosynthesis and N

571 concentrations of co-occurring non-fixers but does not modulate their responsiveness to

572 carbon dioxide enrichment. Oecologia 137:22-31

573 Long SP, Ainsworth EA, Rogers A, Ort DR (2004) Rising atmospheric carbon dioxide: plants

574 FACE the future. Annu. Rev. Plant Biol. 55:591-628

575 Luo Y, Su B, Currie WS, Dukes JS, Finzi A, Hartwig U, Hungate B, McMurtrie RE, Oren R,

576 Parton WJ, Pataki DE, Shaw MR, Zak RD, Field C (2004) Progressive nitrogen limitation of

577 ecosystem responses to rising atmospheric carbon dioxide. BioScience 54:731-739.

578 Mayor JR, Schuur EA, Henkel TW (2008) Elucidating the nutritional dynamics of fungi

579 using stable isotopes. Ecol. Lett. 12:171-183

580 Miglietta F, Peressotti A, Vaccari FP, Zalder A, DeAngelis P, Scarascia P (2001) Free-air

$581 \mathrm{CO}_{2}$ enrichment (FACE) of a poplar plantation: the POPFACE fumigation system. New

582 Phytol. 150:465-476 
Millard P, Sommerkorn M, Grelet G (2007) Environmental change and carbon limitation in trees: a biochemical, ecophysiological and ecosystem appraisal. New Phytol. 175:11-28

Norby RJ (1987) Nodulation and nitrogenase activity in nitrogen fixing woody plants stimulated by $\mathrm{CO}_{2}$ enrichment of the atmosphere. Physiol. Plantarum 71: 77-82

Norby R, O’Neill EG, Gregory Hood W, Luxmoore RJ. (1987) Carbon allocation, root exudation and mycorrhizal colonization of Pinus echinata seedlings grown under $\mathrm{CO}_{2}$ enrichment. Tree Physiol. 3: 203-210

Norby RJ, Delucia EH, Gielen B, Calfapietra C, Giardina CP, King JS, Ledford J, McCarthy HR, Moore DJP, Caulemans R, De Angelis P, Finzi AC, Karnosky DF, Kubiske ME, Lukac M, Pregitzer KS, Scarascia-Mugnozza GE, Schlesinger WH, Oren R (2005). Forest response to elevated $\mathrm{CO}_{2}$ is conserved across a broad range of productivity. P. Natl. Acad. Sci. USA $102: 18052-18056$

Norby RJ, Iversen CM (2006) Nitrogen uptake, distribution, turnover, and efficiency of use in a $\mathrm{CO}_{2}$-enriched sweetgum forest. Ecology 87:5-14

Oren R, Ellsworth DS, Johnsen KH, Phillips N, Ewers BE, Maier C, Schäfer KVR, McCarthy H, Hendrey G, McNulty SG, Katul GG (2001) Soil fertility limits carbon sequestration by forest ecosystems in a $\mathrm{CO}_{2}$-enriched atmosphere. Nature 411:469-72

Pacala SW, Hurtt GC, Baker D, Peylin P, Houghton RA, Birdsey RA, Heath L, Sundquist ET, Stallard RF, Ciais P, Moorcroft P, Caspersen JP, Shevliakova E, Moore B, Kohlmaier G, Holland E, Gloor M, Harmon ME, Fan S-M, Sarmiento JL, Goodle CL, Schimel D, Field CB. (2001) Consistent land- and atmosphere-based U.S. carbon sink estimates. Science 292:23162320 
605

606

607

608

609

610

611

612

613

614

615

616

617

618

619

620

621

622

623

624

625

626

Poorter $\mathrm{H}$, Navas $\mathrm{M}$ (2003) Plant growth and competition at elevated $\mathrm{CO}_{2}$ : on winners, losers and functional groups. New Phytol. 157:175-198

Postgate JR (1998) Nitrogen fixation. Cambridge University Press, Cambridge, UK

Reich PB, Hobbie SE, Lee T, Ellsworth DS, West JB, Tilman D, Knops JMH, Naeem S, Trost J (2006a) Nitrogen limitation constrains sustainability of ecosystem response to $\mathrm{CO}_{2}$. Nature 440:922-925

Reich PB, Hungate BA, Luo Y (2006b) Carbon-Nitrogen interactions in terrestrial ecosystems in response to rising atmospheric carbon dioxide. Annu. Rev. Ecol. Syst. 37:611636

Robinson D (2001) $\delta^{15} \mathrm{~N}$ as an integrator of the nitrogen cycle. Trends Ecol. Evol. 16:153-162 Roggy JC, Moiroud A, Lensi R, Domenach AM (2004) Estimating N transfers between $\mathrm{N}_{2}$ fixing actinorhizal species and the non- $\mathrm{N}_{2}$-fixing Prunus avium under partially controlled conditions. Biol. Fert. Soils 39:312-319

Sanborn P, Preston C, Brockley R (2002) $\mathrm{N}_{2}$-fixation by Sitka alder in a young lodgepole pine stand in central interior British Columbia, Canada. Forest Ecol. Manag. 167:223-231

Saugier B, Roy J, Mooney HA (2001) Estimations of global terrestrial productivity:

converging toward a single number?. In: Roy J, Saugier B, Mooney HA (eds) Terrestrial Global Productivity. Academic Press, San diego, pp 543-557

Shearer GB, Kohl DH (1986) $\mathrm{N}_{2}$ - fixation in feld settings: estimations based on natural ${ }^{15} \mathrm{~N}$ abundance. Aust. J. Plant Physiol. 13:699-756

Smith A (2011) The effect of atmospheric $\mathrm{CO}_{2}$ enrichment on biogeochemical cycling of temperate forest ecosystems. PhD dissertation, University of Wales, Bangor 
Soloman S, Qin D, Manning M, Alley RB, Berntsen T, Bindoff NL, Chen Z, Chidthaisong A, Gregory JM, Hegerl GC, Heimann M, Hewitson B, Hoskins BJ, Joos F, Jouzel J, Kattsov V, Lohmann U, Matsuno T, Molina M, Nicholls N, Overpack J, Raga G, Ramaswamy V, Ren J, Rusticucci M, Somerville R, Stocker TF, Whetton P, Wood RA, Wratt D (2007) Technical Summary. In: Soloman S, Qin D, Manning M, Chen Z, Marquis M, Averyt KB, Tignor M, Miller HL (eds) The Physical Science Basis. Contribution of Working Group I to the Fourth Assessment Report of the Intergovernmental Panel on Climate Change. Cambridge University Press, Cambridge, UK, 19-92

SPSS for Windows, rel. 17.0.0 2008. Chicago: SPSS inc.

Teklehaimanot Z, Sinclair FL (1993) Establishment of the silvopastoral network experiment site, Henfaes, Bangor. Agroforestry Forum 4:18-21

Temperton VM, Grayston SJ, Jackson G, Millard P, Jarvis PG (2003) Effects of elevated carbon dioxide concentration on growth and nitrogen fixation in Alnus glutinosa. Tree Physiol. 23:1051-1059

Tissue DT, Megonigal JP, Thomas RB (1997) Nitrogenase activity and $\mathrm{N}_{2}$ fixation are stimulated by elevated $\mathrm{CO}_{2}$ in a tropical $\mathrm{N}_{2}$-fixing tree. Oecologia 109: 28-33

Unkovich M, Herridge DF, Peoples MB, Boddey RM, Cadisch G, Giller K, Alves B, Chalk PM (2008) Measuring plant-associated nitrogen fixation in agricultural systems. ACIAR Monograph No.136. Canberra: Australian Centre for International Agricultural Research.

Vessey JK, Pawlowski K, Bergman B (2005) Root-based N ${ }_{2}$-fixing Symbioses: Legumes, Actinorhizal Plants, Parasponia sp. and Cycads. Plant Soil 274:51-78

Vogel CS, Curtis PS, Thomas RB (1997) Growth and nitrogen accretion of dinitrogen-fixing Alnus glutinosa (L.) Gaertn. Under elevated carbon dioxide. Plant Ecol. 130:63-70 
650 Zak DR, Holms WE, Finzi AC, Norby RJ, Schlesinger WH (2003) Soil nitrogen cycling 651 under elevated $\mathrm{CO}_{2}$ : a synthesis of forest FACE experiments. Ecol. Appl. 13:1508-1514 
Table 1 Results of univariate GLM for characteristics of trees of three species (Alnus glutinosa, Betula. pendula and

Fagus sylvatica) growing in monoculture or mixture (Mix/Mon) at ambient or elevated (ambient $+200 \mathrm{ppm} \mathrm{CO}_{2} \mathrm{growing}$ in the BangorFACE experiment. Presented are $P$-values from the analyses of $\delta^{15} \mathrm{~N}$, soil-to-leaf nitrogen enrichment factor $(E F)$, total leaf $N$ per tree $\left(N_{\text {TOTAL }}\right)$, leaf $N$ per unit area $\left(N_{\text {AREA }}\right), N$ per unit mass $\left(N_{\text {MASS }}\right)$ and $N$ derived from soil $\left(N_{\text {dfs }}\right)$.

Significant $(P<0.1)$ effects are in bold.

\begin{tabular}{llllllll}
\hline Effect & d.f. & $\delta^{15} \mathrm{~N}$ & $\mathrm{EF}$ & $\mathrm{N}_{\text {TOTAL }}$ & $\mathrm{N}_{\text {AREA }}{ }^{a}$ & $\mathrm{~N}_{\text {MASS }}{ }^{a}$ & Ndfs \\
\hline $\mathrm{CO}_{2}$ & 1,6 & $\mathbf{0 . 0 5}$ & $\mathbf{0 . 0 9}$ & 0.43 & $\mathbf{0 . 0 4}$ & 0.96 & 0.928 \\
Species & 2,12 & $<\mathbf{0 . 0 0 1}$ & $<\mathbf{0 . 0 0 1}$ & $<\mathbf{0 . 0 0 1}$ & $<\mathbf{0 . 0 0 1}$ & $<\mathbf{0 . 0 0 1}$ & $<\mathbf{0 . 0 0 1}$ \\
Mix/Mon & 1,6 & $<\mathbf{0 . 0 0 1}$ & 0.25 & 0.16 & 0.75 & $\mathbf{0 . 0 9}$ & 0.571 \\
$\mathrm{CO}_{2}$ x Species & 2,12 & $\mathbf{0 . 0 5}$ & $\mathbf{0 . 0 4}$ & 0.95 & 0.49 & 0.24 & 0.815 \\
$\mathrm{CO}_{2}$ x Mix/Mon & 1,6 & 0.51 & 0.59 & 0.86 & 0.15 & 0.34 & 0.590 \\
Species x Mix/Mon & 2,12 & 0.39 & 0.78 & $\mathbf{0 . 0 0 1}$ & $\mathbf{0 . 0 0 2}$ & $\mathbf{0 . 0 1}$ & $\mathbf{0 . 0 9 8}$ \\
$\mathrm{CO}_{2}$ x Species x Mix/Mon 2,12 & 0.21 & 0.20 & 0.76 & 0.21 & 0.44 & 0.585 \\
\hline
\end{tabular}

${ }^{a}$ Data were $\log _{10}$ transformed before analysis 
669 Table 2 Results of univariate GLM for impacts on $\mathrm{N}_{2}$ fixation in Alnus glutinosa growing

670 in monoculture or in mixture with Betula pendula and Fagus sylvatica (Mix/Mon) at

671 ambient or elevated (ambient $+200 \mathrm{ppm}$ ) $\mathrm{CO}_{2}$ growing in the BangorFACE experiment.

672 Presented are the $\mathrm{F}$ and $P$-values from the analyses of $\% \mathrm{~N}_{\mathrm{dfa}}$ and $\mathrm{N}_{\mathrm{dfa}}$. Significant

$673(P<0.1)$ effects are in bold. Values are calculated based on the mean obtained from

674 using both $B$. pendula and $F$. sylvatica as reference plants.

\begin{tabular}{llllll}
\hline & & \multicolumn{2}{l}{$\mathrm{N}_{\text {dfa }}$} & & \multicolumn{2}{l}{$\% \mathrm{~N}_{\text {dfa }}$} \\
Effect & d.f. & $\mathrm{F}$ & $P$ & & $P$ \\
\hline $\mathrm{CO}_{2}$ & 1,6 & 1.35 & 0.29 & 0.87 & 0.39 \\
Mix/Mon & 1,6 & $\mathbf{5 . 5 5}$ & $\mathbf{0 . 0 5 7}$ & $\mathbf{5 . 2 1}$ & $\mathbf{0 . 0 6}$ \\
$\mathrm{CO}_{2} \times$ Mix/mon & 1,6 & 1.71 & 0.15 & 2.64 & 0.16 \\
\hline
\end{tabular}

675

676

677 


\section{Figure legends}

Fig. 1 Difference in a) $\delta^{15} \mathrm{~N}$ and b) soil-leaf $\mathrm{N}$ enrichment factor (EF) of leaves of Alnus glutinosa, Betula pendula and Fagus sylvatica growing in the BangorFACE experiment. Presented are mean $\pm S E$ of trees growing in monoculture (Mon) or in a mixture (Mix) of all three species at ambient (filled bars) or elevated (ambient +200 ppm, open bars) atmospheric $\mathrm{CO}_{2}$. Note that the $\mathrm{x}$-axis minimum is -1.9 . This is the expected $\delta^{15} \mathrm{~N}$ for Alnus glutinosa growing with no root N. Statistics results in Table 1

Fig. $2 \delta^{15} \mathrm{~N}$ of leaves of $B$. pendula and $F$. sylvatica trees growing with different numbers of $A$. glutinosa neighbours in the BangorFACE experiment. Box-plots show the median and $25^{\text {th }}$ and $75^{\text {th }}$ percentile; whiskers show the minimum and maximum. Values for zero (0) neighbours are from trees growing in monoculture; the remaining data are for trees growing in a mixture of all three species. Numbers of individual trees are shown for each group. Kruskal-Wallis results: both species together: d.f. $=4, x^{2}=12.94$, $P=0.01 ;$ B. pendula: $\mathrm{X}^{2}=7.78, P=0.1 ; F$. sylvatica: $\left.\mathrm{X}^{2}=5.57, P=0.135\right)$

Fig. $3 \delta^{15} \mathrm{~N}$ (mean \pm SE) of soil in the BangorFACE experiment at three depths at ambient (filled bars) or elevated (ambient $+200 \mathrm{ppm}$, open bars) atmospheric $\mathrm{CO}_{2}$. Pooled data from three different stand types (A. glutinosa, B. pendula and F. sylvatica monoculture or in a mixture of all three species) are presented because there were no significant differences between stands. Bars with different letters are significantly different from each other (Fisher's protected LSD, $P<0.05$ ). Repeated Measures GLM results: Depth $-P<0.001, \mathrm{CO} 2-P=0.034$; Stand $-P=0.69$, Depth $\times$ CO2 $-P=0.32$, Depth $\times$ Stand $P<0.001, C O 2 \times$ Stand $-P=0.98$, Depth $\times C O 2 \times$ Stand $-P=0.50$ 
Fig. 4 Characteristics of three tree species growing in the BangorFACE experiment in monoculture (Mon) or in a mixture (Mix) of all three species at ambient (filled bars) or elevated (ambient +200 ppm, open bars) atmospheric $\mathrm{CO}_{2}$. a) total leaf $\mathrm{N}$ content per tree (upper parts of bars for $A$. glutinosa indicate $\mathrm{N}$ from atmospheric fixation $\left(\mathrm{N}_{\mathrm{dfa}}\right)$, all other bars are $\mathrm{N}$ from soil $\left.\left(\mathrm{N}_{\mathrm{dff}}\right)\right)$; b) leaf $\mathrm{N}$ concentration on an area basis $\left(\mathrm{N}_{\text {AREA }}\right)$; $\left.\mathrm{c}\right)$ leaf $\mathrm{N}$ concentration on a mass basis ( $\mathrm{N}_{\text {MASS }}$ ). Data for a are mean $\pm \mathrm{SE}$, for $\mathrm{b}$ and $\mathrm{c}$ geometric mean $\pm S E$ (note log y axis). Statistics results are in Table 1, results for $\mathrm{N}_{\text {dfa }}$ are in Table 2

Fig. 5 The percent of $\mathrm{N}$ derived from atmospheric fixation $\left(\mathrm{N}_{\mathrm{dfa}}\right)$ in $A$. glutinosa grown in mixture (with B. pendula and $F$. Sylvatica) and in monoculture, under ambient $\mathrm{CO}_{2}$ (filled bars) and elevated $\mathrm{CO}_{2}$ (open bars). Presented are the mean \pm SE. Statistics results are in Table 2 
Figure 1

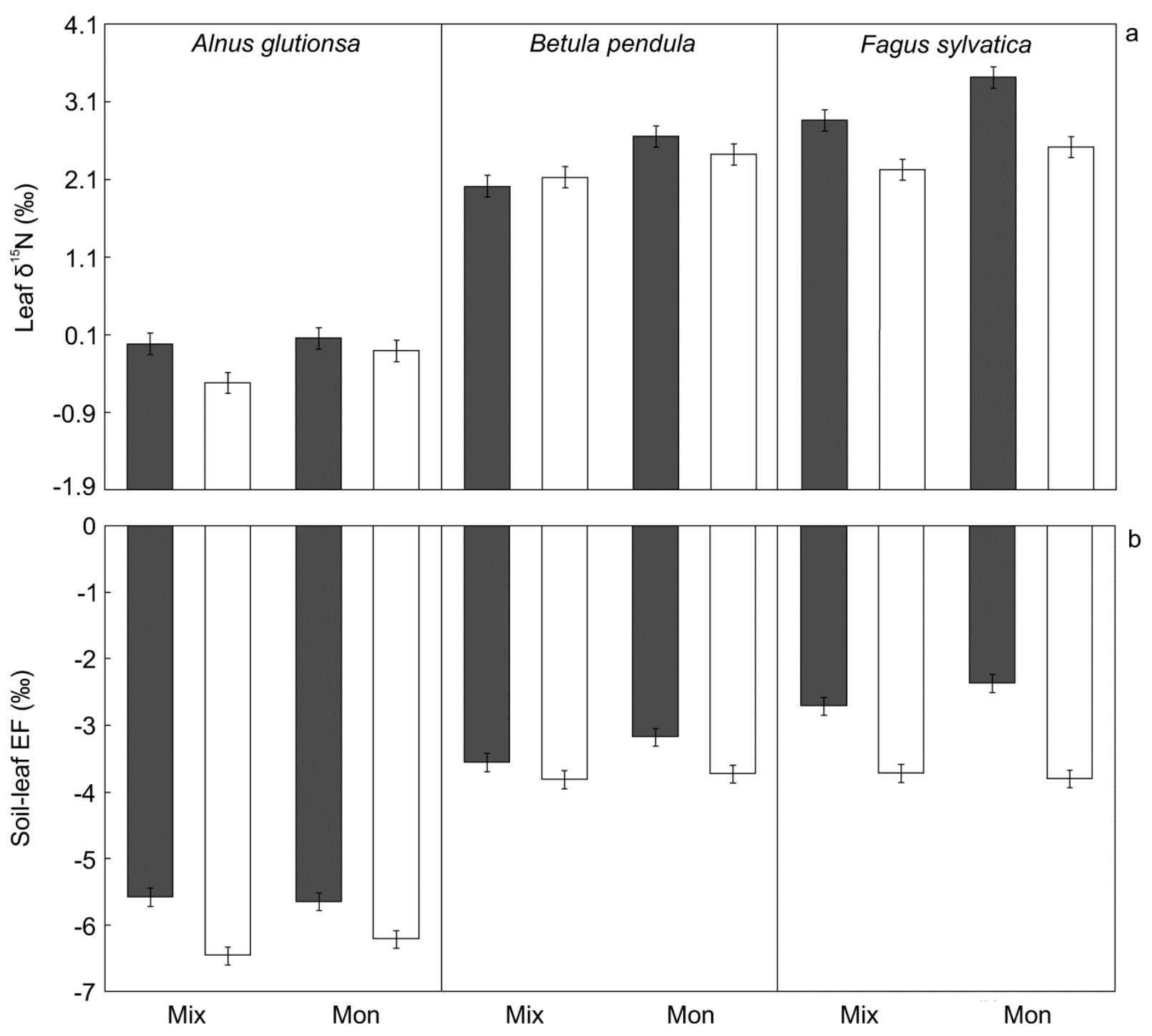


Figure 2.

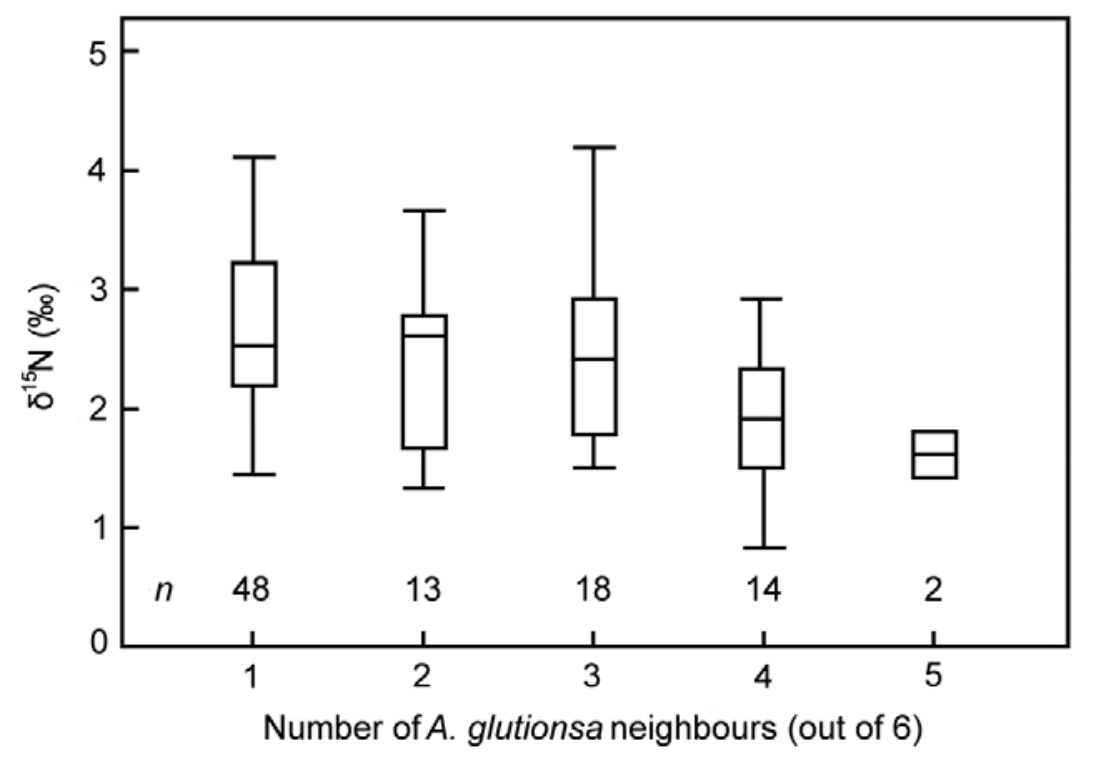


Figure 3.

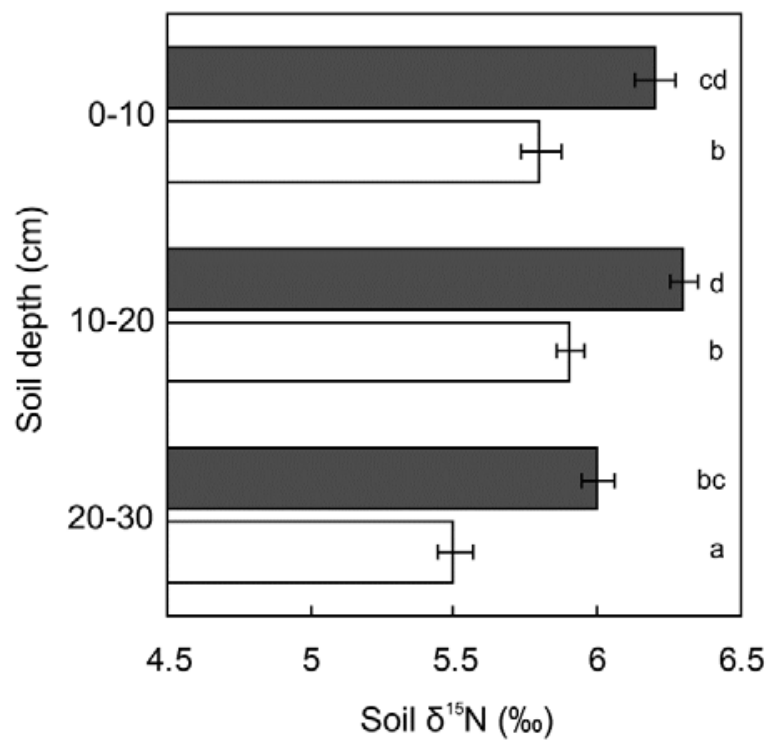


Figure 4.
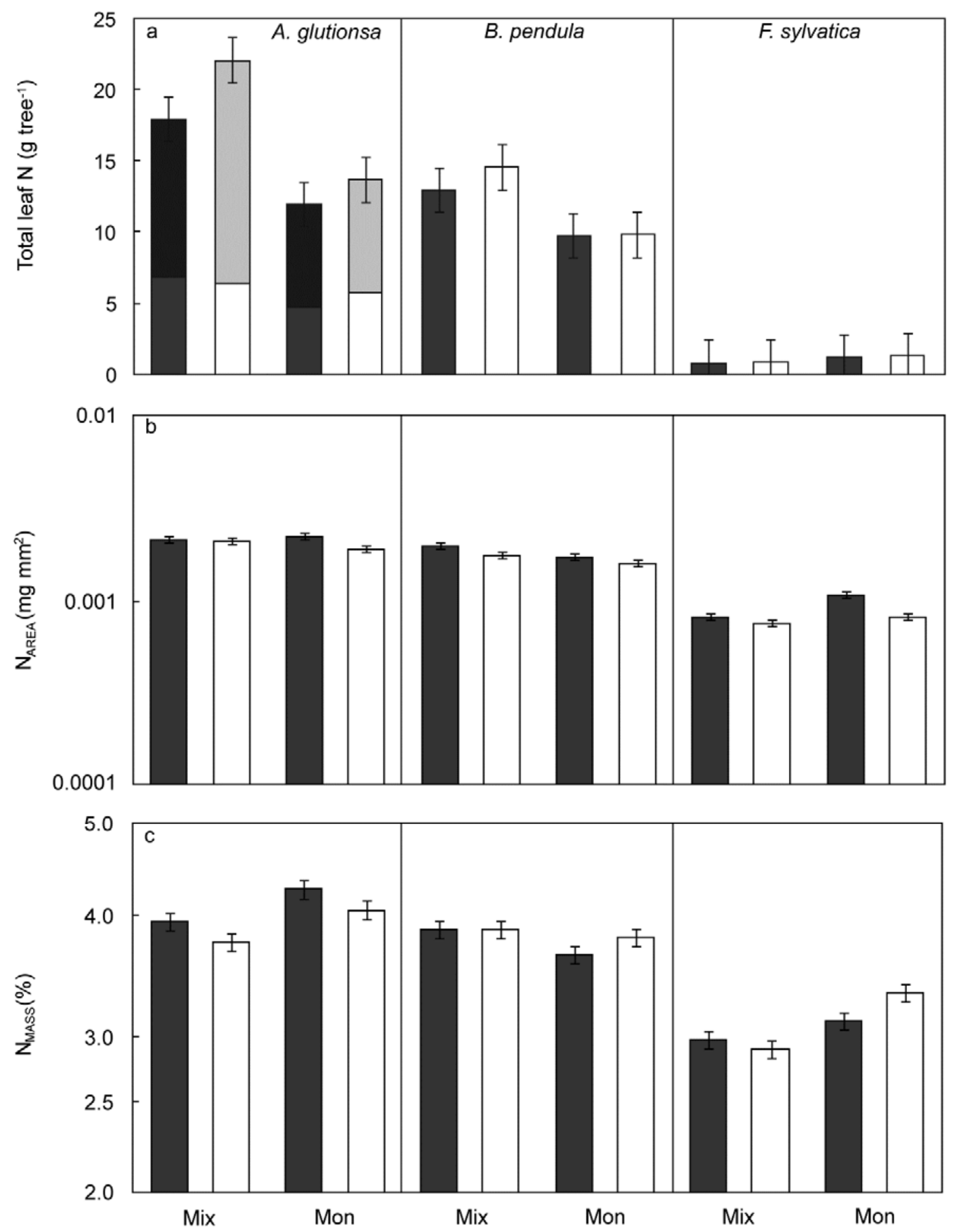
Figure 5.

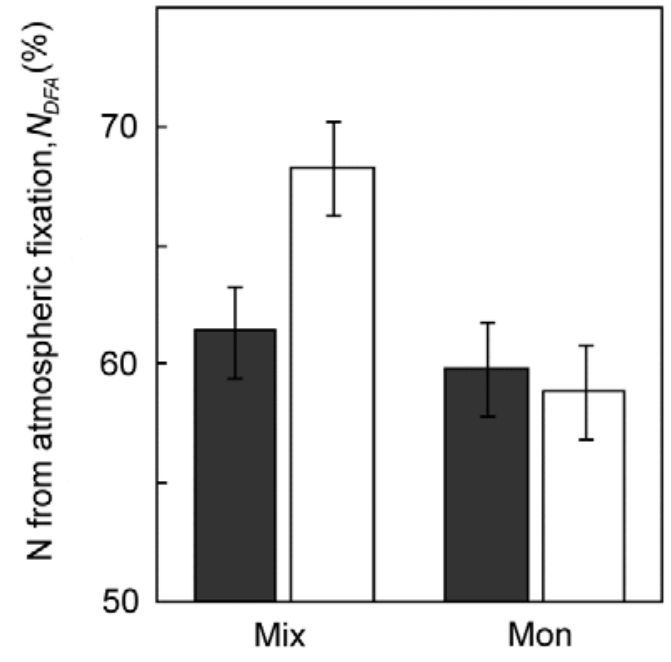

